\title{
最近の石油成因の諸問題
}

\section{崎川範 行*}

\section{1. 序言}

石油の成因などそいうすのは現在ではるうすつかり定 説化されてしまつて，いまさら検討する余地などはある まいと多くの人㛈学ているにちがいない。しかし必ず しもこうは云党ないのであつて，むしろそれはな招石炭 の成因以上飞あい昧模湖としているといつて過言ではな いのである。元来石油は深い地下に拁いて長い歳月のる そに生じたのであって, その成因などというすのは簡単 に割り切れるべき性格のるのではないし，ことに最近の 地学法いては諸学説落しい発展が起つて, 十年以前 にくらべると全く違つた様相をすら呈すると至つて招 り，それて伴なつて石油の成因関してる新らしい幾多 の観点から再検討が行われているのも当然のこととい兄 るであらう。そこで本項汇比較的最近格ける石油の成 因関する諸説を紹介してみたいと思うのである。

最近発展した石油の成因説注としてバクテリアなど

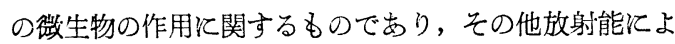
る炭化水素の生成などであるが，それらについて述べる 前に，少しく石油成因論の歴史を顧みてみることにしよ 万。

石油成团論の最初は括とらく 1804 年飞 Humboldt 亿 よつて提唱された火山成因説であろう。ついで Berthelot は金属炭化物から生成したアセチレンの重縮合によつて 石油が生成したと考穴た。そして Moissan 梳石灰石と 石膏が高温度の水と共行反応して炭化水素を生成したと の説を立て, また Mendeleef はマグマから発生する炭 化水素ガスから石油が生成したものであるとしたのであ る。初期の石油成因説はいずれもこれらと類する無機根 源説であつたが, 無機説はFrang Fischer が自らの研

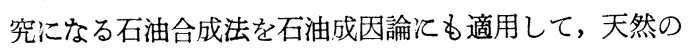
水素と一酸化炭素あるいは炭酸ガスからの合成化よつて 生成したとする説をるつて終止符が打たれている。そし て無機説快半有機物説淮んで, 石炭の乾溜説, 石炭の 水素添加説などが幾つか現われたが，いずれる信ずべき 根扴がなく, やがて 1934 年に Treibsが石油中飞光学 活性物質のほか葉緑素などの植物色素の誘導体である ポルフィリン錯塩類を発見し，さらにホヤの血液の成分 であるバナジウムのポルフィリン錯塩などが見出され て, 石油の無機根源説は全く顧みられないこととなつた
のである。

そこで有機物根源説となるのであるが, 有機説が最初 に現われたのは 1834 年で Reichenbach と Brunet が それぞれ独立住針葉樹の樹脂が石油となつたととを論じ ている。この場合 Reichenbach の方は地熱のために埋 没した針葉樹のテルペンが石油飞転化したと考え, Brunet の方は火山の亜硫酸ガスなどの作用でテルペンが石 油からさらにアスファルトに変化したと考党たのであ る。しかしこのような説はやがて現実の幾つかの矛盾に 岕つて消滅したが, 有機物説は次第に力を得て一般に信 ぜられるようになつた。そして有機物が根源であるとし ても，それが植物根源であるか動物根源であるかについ て諸説紛々とし，さらと海成か陸成か子論争の的となつ た。

1905 年, Potonie は初めて動物根源説を唱光, 腐泥 中に含有される動物脂肪が石油のもとであるとしたが， その後 Englar ほ動物脂肪を乾留して炭化水素を得, そ れをもとにして魚油説を提唱した。これはイワシとの他 の大量の魚群が海底の隆起か海湾の埋没かによつて地中 そ堆積することになり, その脂肪括よび脂肪油が変化し て石油になつたものとしたのである。この説は石油成分 である各種の炭化水素の生成過程もかなりよく説明で き，同時飞石油中に存在する光学活性物質や窒素化合物 の説明もつくので，一時多数の支持を得，わが国でも小 林久平氏核油を酸性白土と共に加熱処理して石油類似 の炭化水素を得て, 地下に颃ける魚油から石油の生成反 応泊土の触媒作用を導入したのであつた。

しかし Englar の説も地質学的には矛盾も多く, 結局 Englar あ腐泥説を一部とり入れるようとなつた。腐泥 説と称するのは水中のプランクトンその他の微生物の遺

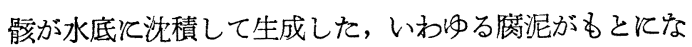
つてできるものであり, 腐泥中の主として脂肪や脂肪油 類が長年月中に石油炭化水素に変ずるという考え方であ る。そして腐泥を考える場合には Potonieのように動物 性脂肪を考它た方が信凅性があり得ることになるである 万。こ5して腐泥説は Dalton, White 等によつて支持 されたが，1922年と高橋純一氏は同じく腐泥説でも海底 腐泥説を提唱している。こうして現在に至るまで, 腐泥 説, ことに海底㦄泥説が最す広く各国の石油学者に支持 されているが, 腐泥中の石油の根源となつた油脂類は, 石油の中に前述の葉緑素の誘導体の発見から主として, 
あるいは少なくとも一部々植物性の油脂であると考光ら れるに至つている。

腐泥説は現在でもな括一番多くの学者によつて認めら れているのであるが，最近ではまた政生物説というのが 有力以発展してきている。といつて腐泥説も一種の微生 物ではあるが，腐泥の場合は微生物の遗䯘が石油の根源 となるのであつて, 最近の微生物説では細菌類の作用に よつて石油が生成するというのである。アメリカのZoBell らほ細菌が石油の形成, 蓄積括よび変質等汇重要な 役割をつをめるものであることを研究し, 石油首中から 発見された細菌を培養して脂肪酸から岸化水素の生成, 脂肪の加水分解, 酸化, 硫酸塩の還元, そしてさら飞母 岩からの石油の離脱の働きまでする現象を認めて石油の 成因の微生物説を主張したのである。

ところで石油の根源ならびと成因なるものは，1935年 飞 Thayer が指摘している通り決して単一の原因㴆せ られるべきものでねなく, 産地や油田によつてそれぞれ 異なるものであり，根源物質にしても生成過程にしてる 著しい変化に富むものと考光られる。したがつて現在も 将来るとれのみが石油の成因であると断定するような成 因論というるのは存在するはずはないのである。

そこで筆者も一つの説として石油の成因に関して天然

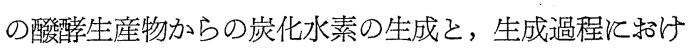
る土壤の触媒作用という発表も行つてみたわけである が, さらに最近では地学的にも広く放射能の役割が重視 されるようとなつたので，それて伴なつて地下の油脂類 が自然放射能のアルファ粒子の作用によつて炭化水素に 変化し, それが石油の根源になつたという研究す生れて きている。

さて最近の新しい諸説までを含めて, 石油成因論の変 遷をたでり，その一つ一つを検討してみると，そのいず れ背定さるべき点が存在すると同時にまた重大な矛 盾子含まれているのである。そしてそれらの諸説を綜合 した結果には五里霧中のような感も抱かれるが，乙かし その中に石油成因というるのの概略の性格が十分に浮び 上つてくるのである。石油成因論ならびと石油鉣床の形 成過程を全般的に論じたらとれとと大部の書物ができ上 つてしまう。そとで本項では石油成因関するごく最近 の興味ある問題の二，三をとり上げ，油脂をほじめ諸有 機物から石油炭化水素が生成する過程を少しく考察して みようと思うのである。

\section{2. 石油炭化水素の生成亡土壤の触媒作用}

石油崖化水素が土壤中の細菌類のいわゆる石油醱睹に よつて, 油脂類, 岸水化物乞の他の有機化合物から生成 乙得る実例があるとしても，とれが石油鉱床を形成する 機会はきわめて稀であると考学る方が妥当であろう。そ 乙て筆者は微生物が石油生成の重要な役割をつとめる場
合定考光るとしても，直接炭化水素を生成するよりも， その根源となり得る比較的単純な有機化合物の生成の方 に大きな役割を占めると考光るべきだとの見解を抱いて いる。そこで石油成因江腐泥説をとる汇せよその他の説 をとるとせよ，それらの有機化合物㐱石油炭化水素に転 化する過程では, 土壤や岩石の接触作用を除外乙て考兄 るととはできないと考光られてくる。

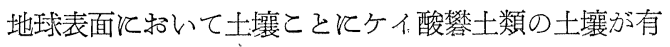

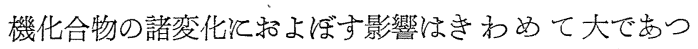
て, セルロース,リグニン等からフミン酸を形成するの そもとの作用は認められるのであるが，石油の生成汇関 してもこの種の土壤の触媒作用は当然重視されるべきる のと考光られる。古くほ小林久平氏は魚油を酸性白土さ 共愺留した際石油炭化水素が生成する事実と, 油田地 帯に和ける酸性白土層の存在とを関連させて, 乞の触媒 作用を論じているが，さらと高橋純一氏は腐泥中の油脂 類が海底土壤のケイ酸, ケイ酸アルミニウム, 酸化鉄な ぞに吸着され, あるいはカルシウム, マグネシウム, 鉄 などの金属セッケンとなつて存在して, やがて瀝青質化 することを推論しているが，これらも上記の意味の土壤 の触媒作用類する考克方とい党るであるう。

しかして地下に和惊る石油生成過程を考觉るまでもな く, 現在酸性白土, 活性白土, コロイド壤土なぞのケイ 酸䙪土土質の土壤や酸化鉄黄土なぞが石油工業や人造石油 工業飞和いて, 各種の炭化水素の化学反応飞対して重要 な触媒作用をすることほ全く実用的応用されているこ そであり，なた脂肪油を原料として潤滑油を合成する場 合飞る，白土を用いて崖化水素類の製造が行われるのる よく知られた事実である。その事実から考光てもこれら の土壤類が石油の生成拉よび変成に大きな役割をはたし ていることはるはや疑う余地がないことが推察されるで あるっ。

ところで地下に和いてある種の有機化合物が土壤の触 媒作用, あるい性その他の作用で石油炭化水素を生成す る場合を考光ると際して, 少なくとも石油鉱床の形成江 役立つ程度の量の問題を考党ると原料有機化合物の種類

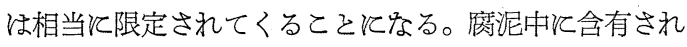
る微生物体の油脂はその一つであると違いないが，地球 上で最も多く生成される有機物を考光れば，とれは当然 植物の炭水化物類々いらととになる。デン粉, 糖類, セ ルロース等の炭水化物は広く全地球上を被い，それらが 土壤中以堆積する機会は限り宗く存在し，圥れは石炭の 根源となつているのであるが, しかし炭水化物から直接 石油炭化水素を生成する過程となると，地下と扔ける条 件ではその推定は困難沈つてくる。だが一方で土壤中 には炭化水素を食つて種々な簡単な有機化合物を生成す る酵母やバクテリアなどの微生物々, きわめて多種類に わ它つて存在する。しかも土壤中のバクテリアを検率す 
ると，注とんど大抵の有機化合物を利用する反応で生育 するものが存在し，また無機化合物学利用して鉄鉱床や イオウ鉱床までつくり上げる㗢きをする鉄バクテリアや イオウバクテリアのよう趁ものまで存在して, 地球化学 的な大きな役割孛ねたしているのである。乙たがつて植 物の大量の炭水化物を消化して, 直接石油炭化水素の生 成を容易ならしめるような化合物をつくりだす微生物も 多数存在すること续い疑いであるう。

さて一般の土壤中普通の貒生物類で宸水化物を他の 簢単な有機化合物に変える働らきをするるのを考觉る

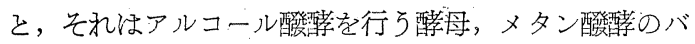
クテリア，五るいはブタノール・アセトン醱醅を行うバ クテリアなどである。これらのうちエチルアルコールと メタンとね，比較的籣単な反応で高級炭化水素を生成す るのは困難か子しれない。じし, ブタノールやアャト ンならばあるい溶易高級な石油炭化水素の形成役 立つか子しれない。

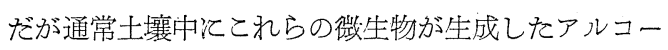
ル類との他の化合物が簢単に検出し得る程度に存在する ことほ稀であつて，これらの醱酵生成物が蓄積する現象 は見出し難い。それは土壤中に特いてはとの生成物を消 化する他のバクテリアが共存して，乙れらが互に均衡を 保つて生育していらからである。乙かて，ひてたび何ら かの条件によつてこの均衡が破れ，一方のバクテリアの みの活動がさかんになれば，山るい注める特定の有機化 合物の生成がその蓄積を生ずる程度の速度に達するのる 可能であると推論できる。地史学的にはむる種の生物, 微生物が，いわりる爆発的と称せらる急激な繁殖它行つ て，一種の岩石を形成するの役立つ場合すら存在す る。したがつて，ある場合に十分石油鉣床の形成に役立 つ程度のアルコール類その他の有機化合物の生成が行わ れなかつたをは断定し得ないであろう。

それではいかなる場合に天然とブタノール・アセトン 醴酵やアルコール醴酵が大規模に起り得るような原因が 生れるであるろか。それは石炭の成因てなるるらな植物 体の堆積が存在した場合, 特矮の好熱バクテリアにより てセルロースやリグニンの加水分解が大規模に行われる

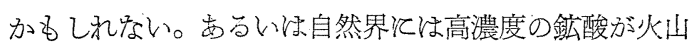
噴出物や温泉によつて大量に流出する場合が存在する。 たと党ば現在でも秋田県の玉川温泉で々0.1 N の塩酸が 約 $100^{\circ} \mathrm{C}$ の高温度で大量飞湧出している。第三紀の石油 層形成の頃には火山活動がきわめて盛んであつたから， この種の高濃度の塩酸などが大規模に流出して植物の堆 積首に侵入し，乙れを加水分解してバクテリアの生育に 好適な培養体である糏類が生成して, それが地上飞滞留 し，あるいほ地中侵入して，酵母やブタノール・アセ トン菌などル大活動を起させた事情が存在したかもしれ 京いのである。
このよろ变場合を想定し得てとすれば，大規模と生成 したアルコール類, ケトン類めるい有機酸の類が土 壤, ことそ活性土壤類の作用によつて濃縮されると同時 そ, その触媒作用によつて脱水されてオレフィン炭化水 素飞転化し, さら飞重合, 縮合, 異性化, アルキル化, 脱水素, 芳香族化, 水素添加等の諸過程を経て石油を形 成するこてが推察されてくる。そしてその場合, 地下の かなりな高温そ高圧が利用されればこの過程ね一層容易 そなるこてが想像されてくるのである。

乙か乙この種の陸地植物成分の醱酵生成物ぶ石油根源 そなることを想定した場合, 石油鉱床にてるなう油田塩 水の存在をいか、説明したらよいであるう。だが油田塩 水が石油海成説の根本になつているとしても，先の成分 壮必ずしも海水の成分とは一致しないし，またをれを化 石海水と考光ても当を得ない場合が多い。油田塩水中の 塩類の含有割合が海水と異なるほか、, 油田塩水中に泳 リチウムが含香れ，なた強い放射能をもつるのも少なく ない。そこで油田塩水が海水ではなくて火山噴出物その 他の鉱水汇由来劣るるのと考克た方が妥当であるか子し

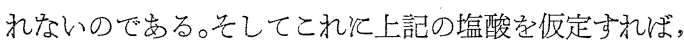
堆積植物の加水分解儿使当れた塩酸の残余々安山岩乞の 他の岩石を分解させて中和されると同時飞，一方飞触媒 作用の強い酸性白土之の他の粘土鉣物定生成させ，それ がさらに石油炭化水素を生成させる触葉となつた飞考 壳れば，一層都合よく説明がつけられてくるのである。

たと壳ば秋田県の雄物川油田を考光て見よう。雄物川 の上流飞前記の玉川温泉が存在して長年月にわたつて 濃厚な塩酸を噴出している。そして地質時代のある時期 にとの活動がほなほだ活潑であつて, 大規模な塩酸の流 出が起つたかもしれない。現在でも玉川ほ流域 5000 町 歩の水田を酸性にして水稻の生育汇著しい障害を与兄て いるのでめる。とこでこの玉川て雄物川油田の成因にあ るいは関係が存在しなかつそとはいえないので岁つて， 玉川のるつ強力な放射能々雄物川油田の塩水の放射性物 質，あるいは含有層の岩石の放射性元素々の関連を研究 したら，あるい任面白い事実妿見出されるか子しれない のである。

そころで筆者々かつて，エチルアルコール，ブタノー ル，アセトンなどを高圧の下で酸性白土，活性白土，そ の他の活性土壤で処理して生成物学検討し, 石油炭化水 素類似の各種の炭化水素が容易江生成するのを認め, そ れらに基づいてブタノール。アセトン醄酵生成物から天 然石油が生成して石油鉣床を形成した可能性を論じた ことがあるのであるが，この場合正ブタノールを処理す ると触某汃アルミナであると主としてオクテン程度のオ レフィン岸化水素が生成し, 酸性白土を触煤そして使用 すれぼオレフィンそ芳香族炭化水素の混合物学生じ，さ らに活性白土を使用すればそのほそんどが芳香族炭化水 
素そなり, 多少の飽和炭化水素が生成するのが認められ たのである。な招エチルアルコール単独ではとの脱水重 合は容易であるとは認められないが，ブタノールとの混 合物で炭素数 6 個の炭化水素が生成する。またアセ卜 ンは容易沃シチレン等の炭化水素汇変化するのであ る。

これらの反応がはたして石油成因直接関与し得たか 否か断言の限りで祢いが，一つの石油成因を示唆す る現象としてはそり上げて考党る価值があるであるう 乙, また石油中の各種の成分炭化水素の成因々, 生成過 程と扔ける触媒作用によつた土壤の性質との関係を論ず る場合の有力な資料とほなり得るるのであるう。そして 腐泥中の油脂類, あるい山との他の原因によつて地中に 存在した油脂類が石油炭化水素儿転化する場合飞る, 同 様活性土壤の作用とその種類辸生成石油の成分の 変化る類推し得るのである。

\section{3. 石油醊酵の微生物}

微生物の遗䯓が堆積してその成分の脂質から二次的飞 石油炭化水素が生成するていう考克方々腐泥説として最 る普通のものであるが, バクテリア類の微生物が直接石 油炭化水素を生成するといら考觉々 1933 年の Seyer, 1934 年の Hammer らの説から始まつている。そして最 近ではアメリカの ZoBell らによつて多くの発表が蛀さ れている。これらの石油䣹酵, あるいはバクテリアの細 胞の一部としての炭化水素の生成夺, とく飞地下飞和け る石油生成過程で立証されたわけではないが, 主として 油田塩水の中から分離されたバクテリアとその実験室に 物ける培湌の結果から推論されているるのなのである。

油田の含有層中存在するといらバクテリアは深海の 海底，たと党ば $10 \mathrm{~km}$, 圧力 $1000 \mathrm{~atm}$ といつ条件で 棲息するバクテリアと類似のものと考光られるが，乙れ らのバクテリアの中には $60^{\circ} \mathrm{C}$ とい高温でも生育した 例が報ぜられて和り，乙たがつて深い油田の含油層中 で，高温度でしかも高圧の下に十分生育するるのである ことが推測されているが，事実 ZoBell らは各地の油井 の塩水の中から類似のバクテリアを分離するの成功し ている。ZoBell はこれらのバクテリア類が数百メート ルの深さの油層飞まで分布することを推測しているが， これらのバクテリア主としてイオウバクテリアに属す ものであつて，乙か子硫酸根を還元する性質をるつた Desulfovibrio そ称せられるものであると認められてい る。このバクテリアはな扮窒素を固定する性質ももつて いるといわれるが，この種の硫酸根還元バクテリアが石 油生成の役割をすると考光るとき，それは油田塩水中に 硫酸根の存在がごく少京い事実の原因であると見なすと とができるのである。しかし現在これらの油井に発見さ れたバクテリア類が，さく井作業中に地表から侵入した
のでは柰いかとの疑問も提起されているのである。

だがこれらのバクテリアは多くはきわめて高温度でも 生育滴し, 数十度 $\mathrm{C}$ で生育するものの注か $98^{\circ} \mathrm{C}$ の温 度でもな和生存するすのが認められている。たと光ば多 くの温泉と执いてはこの種の高温度でな敃繁殖するバク テリアを見出し得るのである。乙たがつて梁さ $1000 \mathrm{~m}$ の含油層の温度が $50^{\circ} \mathrm{C}$ 以上であつても，そとには十分 活動し得るバクテリアが存在して不思議はないのであ る。

さててれらのバクテリアが含油層や油田塩水の中に生 存して，何らかの活動を行う場合にはたして石油成分と なり得る高級炭化水素の生成が期待できるであるらか。 メタンそエチンンを除いては細菌の醱酵作用による炭化: 水素の生成々自然界には顕著な現象としては認められ難

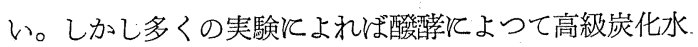
素の生成する事実が認められているのであつて, ZoBell.

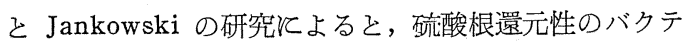
リアは海水中で脂肪酸類を炭素源として堷養した場合に。 高級炭化水素を生成するという事実が報告されている。

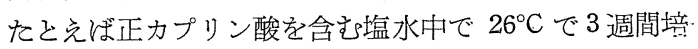
養したところ, $\mathrm{C}_{10} \sim \mathrm{C}_{25}$ の脂助族炭化水素の混合物が相. 当の量生成されるのが認められたといわれる。そしてて

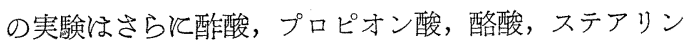
酸, 乳酸等を含む塩水中でる確かめられたのである。

ZoBell ほさら飞土壤中飞存在するメタン酸化バクテ リアの類で, その細胞物質の一部微量の高級炭化水素 を生成するものが岕るのを認めている。とのバクテリア をエーテル抽出するとととよつて蠟状の岸化水素が得ら れているが，乙のバクテリアほ有機の炭素源の存在を必。 要とせず，炭酸塩を唯一の炭素源とし，水素をエネルギ 一源として生育し, 高級炭化水素を生成するのであつ て, たとえば20 l の培養基中で $10.5 l$ の水素を消費し て，148 mg の不ケン化性の油を生成しているのである。 これから計算するとてのバクテリアは $6 \times 10^{-12} \mathrm{mg} / \mathrm{cell}$ /dayの割合で石油を生成し，もしこのバクテリアが地下 の含油層中飞存在す衿ば, 何百万年かの長年月の間飞 ほ，有機物の石油根源物質が存在しなくてる，なた硫酸: 塩類が存在しなかつたとしても，ただ炭酸塩類の還元の

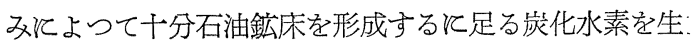
成するはずだていわれるのである。

さらにこれらのバクテリアの培養体に多量の有機化合. 物が存在すると，それらは急激な分解を受け，その分解： 生成物の中《直鎖状のパラフィン炭化水素を多く含む が，その有機物が海澡類である場合には側鎖の多い炭化 水素やナフテン炭化水素が生成するそうである。

ZoBell 以外の研究者によるこの種の研究としては, 1951 年飞 Prevot は Clostridium cauteretseusis そい らバクテリアが脂質を容易に炭化水素に転化するととを 
認めている。そしててのバクテリアはフランスのピレネ 一山脈中の多くの温泉中に見出されるが，この場所はラ ック油田と近いためとその石油の成因に関係があるので はないかというのである。また同年 Hvid-Hansenは, やはり硫酸根還元性のバクテリアで瀝青質の石油状物質 を生成するものを認め, これと Desulforistella hydrocarbonoblastica そ命名している。乙の場合は培養基 中，炭素源としてほ炭酸塩を用い；水素源としてギ酸を 使用しているのである。

さて日本ではこの種の研究は余り行われてい尔いが， 温泉も多いし高温度の酸性泉の中に微生物の繁殖してい るのもしばしば観察されるし，これらとついて実験を行 つたら大分面白い結果が得られそらである。こと酒本 ほイオウバクテリアの種類々多そうであるし，これらに ついてる秋田や新潟の油田と結びつけて研究してみたら 面白い火違いないそ思われるのである。

\section{4. 石油の成因と放射能}

戦後核反応や放射性元素の地球化学的研究がさかんに なるにつれて, 地球内部, こと地款中に存在する放射 性元素の役割が種々の方面で重要視されるようになつて いる。たと党ば地熱や地球内部のマグマの成因なぞであ るが，現在で注これらがウラン，トリウム，カリウムな ぞの岩石中含季れる放射性元素の放射性エネルギーの

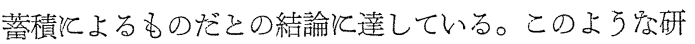
究ならびそ原子力資源としてのウラン，トリウムの探率 から各種の岩石中の放射性元素の含有量子一層広沉汇調 査されるようとなつていうが，その結果ねつい石油の 成因と岩石の放射性元素々の関係が論ぜられる事情まで 生じたのでめる。

石油の成因々放射能そいう問題が提起されるようとな つた最初は，主こしてり連崢でで調べられた油田塩水の 放射能の研究から始まつていると思わ秃る。油田塩水飞 はしばしばかなり強力な放射能をるつるのが岕り，その 点から油田塩水が海水々ほ独立のものであるとの考方方 が生れてきた。そしてさらに油田の頁岩類に放射性元素 が多い事実戸見出されて, 石油の成因てこれらの放射性 元素との関連性が考克られることになつたので岁る。油

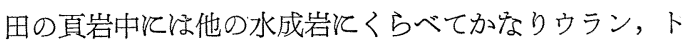
リウムの含有量が多く, 一般の眇岩のウラン, トリウム 合計が $10^{-5} \sim 10^{-7} \%$ であるのに対し, 油田真岩には 10 -3\%のウラン，トリウムが含まれている。この量は大体 花崗岩やペグマタイトの場合と同程度であり, そこで油 田頁岩は将来原子力資源の一つと等る可能性すら考光ら れはじめているのである。

油田頁岩の放射性元素の由来决は，筆者らはイ オン交換とよつて油田塩水中のウラン, トリウムを濃縮 したすのであるて考光, その塩水中の放射性元素は塩水
の根源が火山性の鈗水にあつて，そのため飞第 2 節汇述 べた理由によつて由来したものであると考克ていたので あるが，とれはこるかくとして頁岩や塩水放射性元素 が多く存在するということは，石油の成因めるいはとの 変成と放射能とが何らかの関係学もつのでங宗いかとの 疑問を生ぜさせるのと十分であるとい方であるう。

Lind そ Bardwell ほかなり古くから各種の物質飞対 する放射線の化学作用を研究しているが，1926年にもし 地下でガス状の炭化水素がアルファ粒子の照射を受ける

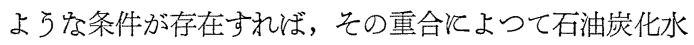
素が生成するであるうとの説をだしているのが，石油の 成因関して放射能がこり上げられて最初であるら。

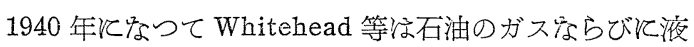
体炭化水素は地下で種々の有機物が放射線の作用を受け て生成したという一つの可能性を論じている。

さて，放射線そ炭化水素の関係であるが， Lind

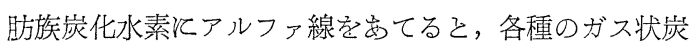
化水素々液体岸化水素宗らび水素が生成するこいつて いる。たと党ばメタンがアルファ線をらけをと, エタ ン, プロ,゚ン, ブタン, ペンタン, その他高級の炭化水素 ならび水素が生成し，エタンはらば水素そメタンが生 成する法か液体の孷化水素が多く生成する。1946 年に Honig そ Sheppard ほラドンからのアルファ粒子を, サ イクロトロンでの重陽子を用いてメタンとブタンの照射 を行い, 質量分析器を用いて生成物を検討し汇結果, か つての Lind の観察を雄かめている。そしてブタンから の生成物中, 不飽和宸化水素皇その一部がオレフィンで めり，一部芳香族となつているのを認めている。その 他高級岸化水素汇対する研究報告は少ないようである が，固体のパラフィンに対するアルファ粒子の作用に関 しては, 主として水素の生成が認められ, 脱水素反応の 起るこてが報ぜられている程度である。しかし，これら の現象は石油の成因関する放射能の作用妾十分想像さ せる刺㦸となつて，主としてメタンなどのガス状炭化水 素が地下の自然放射能の作用によつて重合し, 石油の生 成をもたらしたという説が立てられたのであつた。

こころで Whitehead らはそれよりあむしろ他の有機 化合物江放射線が作用して石油炭化水素が生成すると考 兄る方を妥当として，主として海底腐泥中の脂質から生 じた脂肪酸にアルファ粒子が作用して石油岸化水素が生 成したとの説を提出している。

Whitehead そ Sheppard ほガラス球の内面治脂肪酸 を塗布し，内部を真空にした後ラドンを導入してアルフ ア線照射を行い，反応生成物の検討を行つたのである が，その結果主として脱カルボキシル反応が起つて炭化 水素が生成することを認めている。

$$
\begin{aligned}
& \mathrm{CH}_{3}\left(\mathrm{CH}_{2}\right)_{x} \mathrm{CH}_{2} \mathrm{COOH} \rightarrow \mathrm{CH}_{3}\left(\mathrm{CH}_{2}\right)_{x} \mathrm{CH}_{3}+\mathrm{CO}_{2} \\
& \mathrm{CH}_{3}\left(\mathrm{CH}_{2}\right)_{x} \mathrm{CH}_{2} \mathrm{CH}_{2}\left(\mathrm{CH}_{2}\right)_{y} \mathrm{COOH} \rightarrow
\end{aligned}
$$




$$
\mathrm{CH}_{3}\left(\mathrm{CH}_{2}\right)_{x} \mathrm{CH}=\mathrm{CH}\left(\mathrm{CH}_{2}\right)_{y} \mathrm{COOH}+\mathrm{H}_{2}
$$

そしてとれらの反応が地下で起つて石油が生成するとと を想定しているのでめるが，一方油田頁岩中のウラン， トリウムの含有量からラジウムの量を計算し, 含油層 1 $\mathrm{g}$ 中のラジウムの量を約 $4 \times 10^{-12} \mathrm{~g}$ そ推定して, その放 射能のエネルギーを $2 \times 10^{20} \mathrm{e} . \mathrm{V} . / 10^{6}$ year そ算出してい るが，卡の数字をるとにして100万年間含油首中の有 機物から $1.67 \times 10^{-4} \mathrm{~g}$ の炭化水素が生成するとの結論 を出しているのである。

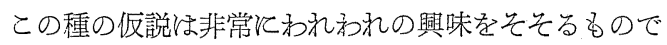
岕るが，地質学的㰸討をすれば種々の矛盾がやほり指 㹍されるこそになるのであるう。乙かし地設中の放射能 の働きは地球化学的に各種の方面飞種々の重要な役割 をつそめているものであることは間違いないであるう。 したがつてある油田のある石油の成因にはこの種の放射 能が大き役割をはたしたと考觉てよい場合があるとら がいないのである。

\section{5. むす び}

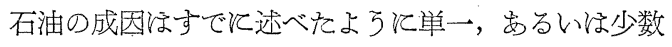
の原因に帰せられるべきものでほないであるう。石油炭 化水素が生成される過程注多数の道己多数の条件が存 在する。乞してそれらが綜合されて石油の一般的宗成因 が考光られるべきであるう。石油の成因々多くの地学的 な問題汇くらべて比較的単純のようとも考光られる。乙
か乙宋和地質学, 化学, 物理学, 地球物理学, 微生物学 ふで各方面の科学の領域の協力を俟たなければ容易に結 論には到達できないのであろう。その意味でな招今後に まつ興味深い研究課題が多大存在しているのであつ て, それらの研究の発展は単に地学的な問題だけではな く, 石油資源の探率や採掘, さらと精製や石油化学まで を含めての産業に重要な役目をすることを十分認識しな ければなら少いであるう。

現に石油微生物学ほ石油の化学探鉱法の発達寄与し ているし, 油田面岩や含油層の放射能の検出々採掘に際 して検層器々応用されて重要な役割軍つとめ始めている のである。筆者は日本に和いてもとの種の問題はもつと 重要課題てして取り上げらるべきだと考えているのであ る。

\section{主な参考文献}

高橋純一, 石油礦床の成因 (昭 7 )

ヴエルナドスキー著, 高橋続一訳: 地球化学 (昭 8 ) 崎 川範行, 有機地球化学反忘関する研究第 $6 \sim 9$ 報 (日 化, 72, (1951))

E. Beerstecher, "Petroleum Microbiology" (1954). W. L. Whitehead, "Hydrocarbons Formed by The Effects of Radioactivity and Their Role in The Origin of Petroleum" (1954) (Nuclear Geology) E. ZoBell, The Oil Weekly, 120, No. 12, (1946) Osnizkaja, -Priroda No. 4 (1948) 